\title{
AMERICAN SUBURBAN
}

\author{
A Thesis Presented
}

by

James Michael Ashworth

Approved:
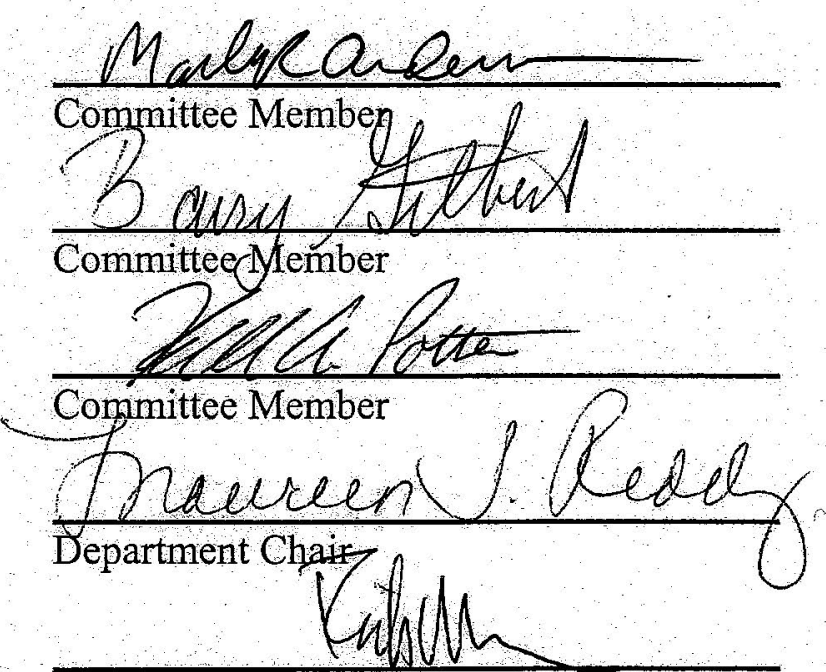

Dean, School of Graduate Studies

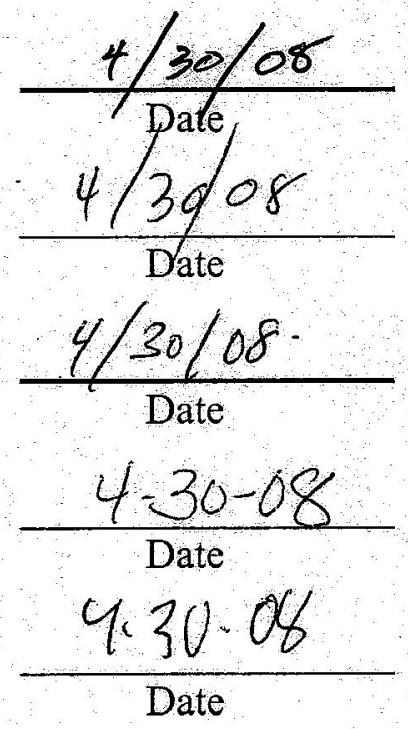

